\title{
Recruitment System for Women's Legislative Candidates in PKS\&PKB in Indonesia
}

\author{
Luky Sandra Amalia \\ Centre for Political Studies \\ Indonesian Institute of Sciences (LIPI) \\ Jakarta, Indonesia \\ sandra_thok@yahoo.com
}

\begin{abstract}
Democracy and Islamic interpretation toward representation of women in politics is still a debate. Indonesia is one example of democratic countries with Muslim majority population. Although the Indonesian constitution guarantees the equal rights between women and men, the proportion of women's representation is lower than the critical mass. However, the proportion of women's legislators is a result of the recruitment systems conducted by the political parties. Therefore, this paper evaluates the recruitment systems of candidates for the Indonesian parliament in two -Islamic and Muslim-basedparties, the Prosperous Justice Party (Partai Keadilan SejahteraPKS) and the National Awakening Party (Partai Kebangkitan Bangsa-PKB) in Indonesia. This paper argues that those parties have not had special treatments to enhance women's chances of winning parliamentary seats in elections. As the aim of PKS and PKB is to win the votes, they tend to nominate those who have experience and capacity, such as the incumbents and senior cadres. However, the Islamic interpretations do not matter. PKS allows women to be members of parliament as they are not considered to be leaders in such a role and PKB does not have special requirements regarding religion.
\end{abstract}

Keywords-recruitment systems, political parties, women, Islamic interpretations, Indonesia

\section{INTRODUCTION}

The relationship between democracy, Islamic interpretations and women's representation is resonance in Indonesia. Indonesia is the third largest democracy in the world with a majority Muslim population (13.1\%) (Pewforum, 2015) . Indonesia has ratified the Convention on the Elimination of All Forms of Discrimination Against Women (CEDAW) in 1984. The gender equality is also stated in the Indonesian constitution and law of human rights. Nevertheless, the proportion of women's representation in parliament is still low at $17 \%$ (KPU, 2014) which is far lower than the critical mass (30\%). This is a result of the recruitment systems conducted by parties. Therefore, this paper evaluates the recruitment systems of candidates for the Indonesian parliament in two -Islamic and Muslim-based-parties, the PKS and the PKB in Indonesia. This paper argues that parties have not had special treatments to enhance women's chances of winning parliamentary seats in elections.

There have been some research conducted by scholars and activists related to this topic. For example, in 2015 the Center for Political Studies, Indonesia University) analyzed the electoral bases of the elected candidates from all parties (Samosir et al., 2015), but it did not focus specifically on the women's issues. Therefore, this research is needed to enrich the references about women's and politics in Indonesia. This qualitative research was conducted in three provinces -DKI Jakarta, West Java and East Java. Jakarta is the capital city of Indonesia where the central offices of the political parties and many NGOs concerned with electoral matters are located. The West Java and East Java Provinces are the basic constituent areas of the Prosperous Justice Party (Partai Keadilan Sejahtera-PKS) and the National Awakening Party (Partai Kebangkitan Bangsa-PKB) respectively, but contributed less to the increasing the number of female candidates.

PKB was formed in 1998 by the chairman of the Nahdlatul Ulama-NU (PKB, 2012). NU is the biggest and traditional Islamic organization which was established in 1926 (Dewi 2015, 11). Therefore, PKB is considered as Muslim-based party although its principle is Pancasila. On the other hand, PKS uses Islam as its party principle (The Articles of Association and by-Laws of the Party 2012, article 2). This party was born from the Tarbiyah (education) movement which has existed in Indonesia through campuses and schools since the 1980s (Nasiwan 2015, 1). The Tarbiyah movement, which has been inspired by the Muslim Brotherhood in Egypt, believes that Islamic teachings are syumuliah (comprehensive), thus, politics is a part of dakwah (religious call/to proselytize) (Nasiwan 2015, 1). In 1998 this movement was transformed into a political party - called Partai Keadilan (PK, the Justice Party). Since PK failed in the 1999 general election, it changed its name to PKS in 2002 to run in the 2004 election .

\section{THEORETICAL FRAMEWORK}

Political parties can be gate-keepers of women's representation in parliament. In general, recruitment systems consist of two models, namely open and close systems (Norris 2006, 95). Open recruitment systems usually run inclusively since they are done openly and involve citizens widely, not only party elites. Conversely, close recruitment systems only involve members of the party, especially the party elites exclusively. The recruitment process is the most decisive stage because this step produces the people's representatives (Hazan 2009, 109).

Recruitment process is a crucial issue for female candidacy since there are several stages which involve different actors, 
such as the women themselves, political parties and voters. According to Matland $(2005,93)$, there are three stages that women who willing to participate in this process need to pass to achieve political office. First, woman has to select herself to be candidate. In this early stage, a woman needs to ask herself and decide whether she desires to enter into the candidacy process. This stage influences by personal ambition, resources and opportunities (Matland 2005, 94). In some communities, a woman who desires to nominate herself is considered ambitious and breaking the customs. Second, woman has to be selected as a candidate by a political party. The party's gatekeepers, especially the leaders of party, will play essential roles for recruiting and nominating candidates for their partylist (Matland 2005, 94). Generally, there are two patterns to select candidates that are used by political parties. The first is the patronage-oriented system which emphasizes the loyalty of those who are in power positions or, in other words, prioritize incumbents (Matland 2005, 95). In the second pattern, the bureaucratic-oriented system, the selection process is based on standards and does not consider those who are in power positions (Matland 2005, 95). However, the most important reason for political parties to recruit and nominate someone is to maximize a party's votes. This candidacy process occurs within the party and influences the next stage, namely candidates' selection by voters - the voter selection stage.

\section{RECRUITMENT PROCESS IN THE PKS}

As the PKS calls itself a dakwah (religious call/to proselytize) party, they argue guided by Islamic interpretations, including in the candidate recruitment process. Their cadres, who have roles as parliamentary members, are recognized as the ambassadors of dakwah in the parliament. Therefore, the cadres are not allowed to self-select themselves as candidates but are appointed by the party. If there is a candidate who is considered to have personal ambition, the party might not accommodate this person in the party-list. This condition does not fit with Matland's $(2005,94)$ first requirement -that women should have personal ambition-. It means that, systematically, PKS inhibits the personal desire of women to progress in the recruitment process of candidates, even in the early stages.

PKS also does not have a special mechanism to enhance women's representation in their candidacy process within the party. There are two avenues to choose prospective candidates, namely through the mentoring units and the structural party meeting. At different times and places, the cadres of the mentoring unit and the party's boards, who hold kader madya (middle cadre refers to the middle level of the tiered regeneration system of PKS), name the desired prospective candidates who meet the criteria, as defined by the party . Then, the final decision is made in the Majelis Syuro (the highest of the party's boards). This decision is absolute and cannot be changed unless the candidates have crucial explanations.

Various party spokespersons gave a number of reasons why PKS prefers to nominate men at the top of the list. The first is, competition in electoral districts is very hard as a result of the open-list and the winner takes all system. Therefore, PKS seeks to nominate candidates who can maximize their capacity to visit the district during the campaign period to obtain wider votes . Those usually are men since they are not bound by domestic duties. Women have limited resources, both social and financial capital. Thus, the party would nominate women to the top of the list if they are considered to meet the criteria. For example, Herlini Amran from the district Kepulauan Riau always gained number 1 position on the party-list because she has a social base, financial capacity, and is mobile. In that district, there is no man who is able to challenge her capacity .

The second reason why PKS prefers to nominate men is that women are perceived to have other priorities then politics. According to the provincial level party board, many female cadres tend to be involved in other areas, such as social community and education. The third reason is women cadres are often at reproductive age and have many children and this limits their mobility. In addition, party meetings usually occur in the evening since majority of party members are working during the day, so a woman cannot participate unless her husband accompanies her. Also, PKS prohibits husband and wife to be nominated together. In this situation, it was said that a woman will usually defer to her husband. Another factor is woman needs her husband's permission to be involved in politics, including as a parliamentary candidate. Once the party nominates them, the party officials will contact the husband of the women candidate to get his permission .

For the last stage, namely selection by voters, in PKS there is a helping system among the candidates and between the candidates and cadres. For example, during the campaign for the 2009 General Election, Ledia Hanifah as the Chairperson of the Department of Women, gained funding from donors which she distributed to other candidates . Another example is, once the party decides the names of candidates, the cadres who live in the same district create a campaign team for the candidate. This team runs the campaign with their own money, especially when the candidates cannot afford it . In some districts, the campaign teams also include other candidates who are placed well down the party-list. So, those female candidates do not campaign for themselves but they help a woman candidate who is placed on the top of the list to win the votes. This situation might not happen in other party, but in PKS it does since there is a shared understanding among cadres that the party is a tool of their struggle of dakwah in politics. The cadres believe that the appointed candidates are their ambassadors of dakwah in the parliament. This belief is embedded in the soul of the cadres as a result of a long and tiered regeneration system of the party. Thus, PKS contributed only one woman in the current parliament and only three women in the previous parliament.

\section{RECRUITMENT PROCESS IN THE PKB}

The majority of women cadres of the PKB do not have issues with the first step of the recruitment process, namely self-selection. Different from the PKS, PKB does not prevent their cadres from volunteering as prospect candidates. According to a national level party officer during the period of registration, cadres are allowed to register themselves through the party gatekeepers, called the Election Winning Body, and choose their own preferred districts. Although the prospect candidates propose their own preferred district, in the end the chairperson of the party decides in which district and at what 
number on the party-list the candidate will be nominated. The chairperson's decision is final, including any sudden changes regarding the placement of ordinal numbers and electoral districts ahead of the election-day.

PKB does not pay special consideration to women candidates unless they prove to enhance the party's votes. Therefore, the party prefers to re-nominate the current parliamentary members over new candidates since incumbents already have the capital and networks . Besides incumbents, the party also usually prioritizes party officials to be nominated at the top of its party-list . Also, the candidates should have a strong relationship with the NU to win the candidacy process since PKB was established by elites of NU. Therefore, NU becomes the main source of candidates' recruitment $(80 \%)$ and targeted votes . Women's organizations of NU - such as Fatayat, Muslimat and Ikatan Pelajar Putri Nahdhatul Ulama (IPPNU) - become primary sources of women candidates during the recruitment process, as well as the women's wing of $\mathrm{PKB}$, Perempuan Bangsa (PB, the Women of the Nation) . In fact, the members and officials of PB are also activists of those women's organizations. Women who come from NU, but have not been involved yet in $\mathrm{PB}$, can also become candidates with recommendations from its elites . Prior to the election, PKB sends a formal letter to NU to seek its recommendations for cadres who want to run in the candidacy of PKB. The party also opens registration for outsiders of PKB and NU, such as academics and other professionals who are interested to join the candidacy process of PKB (20\%). This group should also have connections with NU, whether their family is affiliated to NU or they ever studied in the schools of NU. If they do not have an affiliation with NU, they can make it by promising to advance NU . NU also becomes the major source of PKB to obtain votes. As the candidates have close relationships with $\mathrm{NU}$, they can easily enter the network of NU, for example by joining groups of recitation and visiting the Islamic boarding schools of NU .

The final stage is election by voters. There was no special support for women candidates but rather for all the potential candidates. Potential candidates refer to those, male and female, who are considered by the party to have a big probability to win votes.

Regarding the influence of Islamic interpretations during the candidacy process, $\mathrm{PKB}$ does not have special requirements related to religion. $\mathrm{PKB}$ believes that religion is given so it is not necessary to ask this of other people. This thought is also influenced by the acts of the founder and the first leader of PKB, Gus Dur, who embraced pluralism. The alignment to pluralism is still maintained by the successors of PKB. Nevertheless, in some electoral districts the fatsun that woman should gain the permission from her husband to run the candidacy process has been still maintained by the party's boards and women's candidates .

\section{CONCLUSION}

Indonesia can be an example for women's representation in politics as it is democratic country with a majority Muslim population. Indonesia has ratified the CEDAW. The equal opportunities between women and men are also stated in the
Indonesian constitution and law of human rights. Nevertheless, the proportion of women's representation in parliament is still low. By evaluating the recruitment process within two Islamic and Muslim-based parties, namely the PKS and the Partai Kebangkitan Bangsa-PK), this paper argues that these parties have not had special treatments to enhance women's chances of winning parliamentary seats in elections. As the aim of PKS and PKB is to win the votes, they tend to nominate those who have experience and capacity, such as the incumbents and senior cadres. The similarities of PKS and PKB are, first, both of them apply the close recruitment system since it involves elites and cadres. Second, they embrace a patronage-oriented system as they prefer to re-nominate male incumbents on the top list. Third, due to Islamic interpretations, PKS allows women to be members of parliament as they are not considered to be leaders in such a role and PKB does not have special requirements regarding religion. The differences between these parties are, first, PKS appoints the candidates as the cadres are not allowed to submit themselves whereas PKB has open opportunity for cadres and outsiders to be their nominees. During the campaign period, candidates and cadres of PKS help each other to win votes, especially to support candidates who are placed on the top of the party, while PKB only supports the potential candidates -women and men- who are considered to have opportunities to win.

\section{REFERENCES}

[1] [1] Dewi, K.H., (2015), Indonesian Women and Local Politics Islam Gender and Networks in Post-Soeharto Indonesia, Singapore and Japan: NUS Press and Kyoto University Press.

[2] [2] Hazan, R.Y., (2009). "Candidate Selection" in Bhakti, I.N. and Nurhasim, M. ed., Panduan Rekrutmen\&Kaderisasi Partai Politik Ideal di Indonesia, Jakarta: KPK dan LIPI, 2016.

[3] [3] Interview with AM (Female), the current PKB women's legislator in the provincial parliament, Surabaya, 19 february 2017.Interview with FR (Male), the Deputy Secretary-General of the Central Board of PKB, Jakarta, 16 January 2017.

[4] [4] Interview with BT (Male), the Treasurer of the PKB's Governing Board of Jawa Timur, Surabaya, 23 February 2017.

[5] [5] Interview with FR (Male), the Deputy Secretary-General of the Central Board of PKB, Jakarta, 16 January 2017.

[6] [6] Interview with HW (Male), the former Chairman of the PKS's Governing Board of Jawa Timur, Surabaya, 21 February 2017.

[7] [7] Interview with IS (Male), the Secretary of of the PKS's Governing Board of Jawa Timur, Surabaya, 22 January 2017.

[8] [8] Interview with LH (Female), the Chairperson of the Department of Women and the Endurance of Family, the Regional Leadershi Council of PKS Jawa Timur.

[9] [9] Interview with LH, the current PKS women's legislator in the national parliament, Jakarta, 13 January 2017.

[10] [10] Interview with LNH (Female), the Chairperson of Perempuan Bangsa (the Women's Nation), the women's wing organization of PKB, and the Former Legislative Candidate in 2009 and 2014 General Election, Jakarta, 17 January 2017.

[11] [11] Interview with the Secretariat Staff (Male) of the Sharia Council of the Regional Leadership Council of PKS, Jawa Barat, Bandung, 18 January 2017.

[12] [12] Interview with SJ (Male), the Former Chairman of the PKB's Governing Board of Jawa Barat, Bandung, 23 January 2017.

[13] [13] Interview with TA (Female), the Executive Director of the NGO of Perkumpulan untuk Pemilu dan Demokrasi (the Associations for Elections and Democracy), Jakarta, 25 January 2017. 
[14] [14] KPU (The Indonesia Election Commission), (2014), Buku Data dan Infografik Pemilu Anggota DPR RI\&DPD RI 2014, Jakarta: KPU.

[15] [15] Matland, R.E. (2005), “Enhancing Women's Political Participation: Legislative Recruitment and Electoral Systems", in J. Ballington and A. Karam. Women in Parliament: Beyond Numbers, Stokholm: IDEA.

[16] [16] Nasiwan, (2015), "Dilemma Transformasi Partai Keadilan Sejahtera (PKS)", Summary of PhD diss, Yogyakarta: Universitas GadjahMada.

[17] [17] Norris. P, (2006), "Recruitment" in Richard S Katz\&William Crotty, Handbook of Party Politics, London: Sage.
[18] [18] Pew Research Center Religion and Public Life, (2015), "10 Countries With the Largest Muslim Populations, 2010 and 2015". Pew Research Center Religion and Public Life, 2 April, www. Pewforum.org.

[19] [19] PKB, (2012), "PKB Lahir dari NU untuk Bangsa", PKB, Pkb.or.id.

[20] [20] PKS, (2012), The Articles of Association and by-Laws of the Party, Jakarta: DPP PKS.

[21] [21] Samosir, et.al., (2015), Potret Keterpilihan Anggota Legislatif Hasil Pemilu 2014, Jakarta: Puskapol UI.

[22] [22] The Law Number 3/1999 about the General Elections for the Members of the National Parliament, Regional Representatives and Local Representatives article 9 verse 1. 